\title{
RELIGIOUS DIVERSITY: A PHILOSOPHICAL DEFENSE OF RELIGIOUS INCLUSIVISM
}

\author{
BERND IRLENBORN \\ Theologische Fakultät Paderborn
}

\begin{abstract}
Faced by the challenge of religious plurality, most philosophers of religion view pluralism and exclusivism as the most accepted and fully developed positions. The third alternative, the model of inclusivism, held especially within the catholic tradition, has not received adequate attention in the debates in philosophy of religion, perhaps as it is based solely on theological grounds. In this essay I offer a philosophical defense of the position of religious inclusivism and give reasons why this position represents the most appropriate position in the face of conflicting religious truth claims.
\end{abstract}

\section{INTRODUCTION}

Religious plurality today presents a significant challenge. There exist a plurality of religious traditions, each with different teachings and practices, and each is further differentiated internally into various movements and interpretations. ${ }^{1}$ To the extent that these traditions are grounded in particular truth claims and call for the dissemination of their own teaching and way of life, many powerful theological, philosophical and political challenges are created. By 'challenge' I mean the cognitive calling into question of the truth of a certain belief or attitude generated by other doctrines or practices. There are at least four ways beliefs can be challenged: One position can negate another (marking a contradictory relationship between propositions), dissent from it (contrary relationship), diverge from it (divergent relationship) or, despite its otherness,

${ }^{1}$ Cf. David Basinger, Religious Diversity: A Philosophical Assessment, Aldershot 2002, 2f.; Hendrik M. Vroom, A Spectrum of Worldviews. An Introduction to Philosophy of Religion in a Pluralistic World, Amsterdam 2006, 254. 
correspond to it (convergent relationship). Concerning the plurality of religious beliefs, I would like to distinguish three spheres in which such challenges are felt:

(1) The intra-religious sphere: In the face of the plurality of religions, a given religious community is prompted to clarify the uniqueness of its own religious beliefs, and explore whether and to what extent the awareness of the religious views of others might lead it to define more precisely or revise its own teachings. ${ }^{2}$

(2) The inter-religious sphere: This is the sphere of debate that concerns models that define the relationship between rival religious truth claims, but also the consequences of the intra-religious questioning of these truth claims.

(3) The extra-religious sphere: This is the sphere where the relationship between plural religious beliefs and other beliefs or convictions is defined within the liberal framework of the secular state. It is also the sphere for debating the conditions under which religious citizens might make public use of reason.

In this essay I focus solely on the second aspect: the inter-religious challenge of religious plurality. From the perspective of theology and philosophy of religion, there are three well-known models of the relationship between the plurality of divergent religious beliefs: exclusivism, inclusivism and pluralism. These theories arise mostly on the basis of epistemological considerations. Exclusivism and inclusivism are related models, insofar as both claim the superiority of a particular religion; they differ roughly in that the other religion is in its core tenets ${ }^{3}$ untrue for the exclusivist, but only partially untrue for the inclusivist. At its core, the term 'pluralism' incorporates at least the following assumptions: (i) the plurality of competing religious truth claims is a fact, and must be accepted, ${ }^{4}$ (ii) there is no generally acknowledged religious metaposition

${ }^{2}$ Cf. Harold Coward, Religious Pluralism and the Future of Religions, in: Thomas Dean (ed.), Religious Pluralism and Truth, New York 1995, 45-63, $45 f$.

${ }^{3}$ Core tenets of a religion are doctrines and teachings to which assent is religiously required of all believers.

${ }^{4}$ As William C. Smith puts it: "Plurality, the existence of diversity, is a fact; pluralism, 
from which to judge rival truth claims, ${ }^{5}$ and (iii) religious truth claims are at best mythologically, not literally, true with regard to the nature of ultimate reality. ${ }^{6}$ The three models also describe the relevant attitudes of different religions toward each other: either a relationship of superiority or one of equality between the different truth claims of the religions. ${ }^{7}$ In virtue of the fact that numerous intricate varieties can be distinguished within the three models, these concepts can be further differentiated though I am not going to do so - and a religious position can contain elements of different models. ${ }^{8}$

Faced by the challenge of religious diversity, most philosophers of religion take the view that pluralism and exclusivism are, according to Philip L. Quinn and Kevin Meeker, "the most fully developed positions". David Basinger claims, there are only "two basic responses to the reality of religious diversity: religious exclusivism and religious pluralism". ${ }^{10}$ In this context inclusivism "faces a less certain future"11 or even, according to John Hick, constitutes a "somewhat astonishing doctrine". ${ }^{12}$ I would

the acceptance of diversity, is an imperative." See William C. Smith, Religious Diversity, New York 1976, xviii.

${ }^{5}$ A version of exclusivism can also be inferred from (ii): see William P. Alston, Perceiving God. The Epistemology of Religious Experience, New York 1993, 274.

${ }^{6}$ Cf. Roger Trigg, Rationality and Religion: Does Faith need Reason?, Oxford 1998, 53. On facets of religious pluralism see: Keith Yandell, Some Varieties of Religious Pluralism, in: James Kellenberger (ed.), Inter-Religious Models and Criteria, New York 1993, 187-211, here 187-194.

${ }^{7}$ Does Comparative Theology constitute, as claimed, a separate model? See James L. Fredericks, Faith among Faiths. Christian Theology and Non-Christian Religions, New York 1999, 9. I do not endorse this view. I think that Comparative Theology does not present a fourth model, but at best a hermeneutically sensitive variant of inclusivism or exclusivism. Here is not the place to give reasons for my claim.

${ }^{8}$ For a detailed description of these models see Gavin D'Costa, Christianity and World Religions: Disputed Questions in the Theology of Religion, Oxford 2009, 3-33.

${ }^{9}$ Kevin Meeker/Philip L. Quinn, Introduction, in: idem (eds.), The Philosophical Challenge of Religious Diversity, New York 2000, 1-37, 27.

${ }^{10}$ David Basinger, Religious Diversity: A Philosophical Assessment, 4.

${ }^{11}$ Ibid., 27. Another reason for the unpopularity of inclusivism might be, as Jonathan L. Kvanvig states, that inclusivism is "the most difficult position to clarify in this scheme". See Jonathan L. Kvanvig, Religious Pluralism and the Buridan's Ass Paradox, European Journal for Philosophy of Religion 1 (2009), 1-26, 3.

${ }^{12}$ John Hick, Religious Pluralism and Salvation, in: Faith and Philosophy 5 (1988), 365-377, 376 . 
like to call these views into question. As Quinn and Meeker have emphasised, although many religious persons hold the inclusivist view, "no one has yet undertaken to provide the same detailed defense of inclusivism that is evident in Hick's defense of pluralism or Alston's defense of exclusivism."13 In this essay, I develop a response to this deficiency and formulate some philosophical arguments towards a defense of inclusivism. Perhaps, because Christians have defended it solely on the basis of theological grounds, inclusivism has not received adequate attention in the debates in philosophy of religion. ${ }^{14}$ The inclusivist position seems to me to be the most realistic and tenable response to the challenge of mediating divergent religious truth claims in the intra- and inter-religious spheres without either relativising all of them to mere mythological statements or deeming only the claims of one religion to be true and the rest to be false. Here is not the place to refer to the extensive debates about pluralism and exclusivism or to give detailed reasons why pluralism and exclusivism are not, in my view, "the most fully developed positions" for coping with conflicting religious truth claims.

I am going to call the position that holds that there is a compatibility among competing religious truth claims epistemic inclusivism, because it pertains primarily to epistemological considerations about religious truth claims and not to theological considerations about the way of salvation. In the first section I analyse the idea of inclusivism within the catholic tradition. In the second section I sketch a philosophical view of inclusivism and give reasons for thinking that it constitutes the most viable position in response to the challenge of divergent religious truth claims. The third section presents a brief conclusion.

\section{THE IDEA OF INCLUSIVISM}

If neither pluralism nor exclusivism are appropriate responses to the problem of religious diversity, what reasons would there then be to

${ }^{13}$ Kevin Meeker/Philip L. Quinn, Introduction, in: idem (eds.), The Philosophical Challenge of Religious Diversity, New York 2000, 1-37, 27.

${ }^{14}$ See for instance Karl Rahner's famous concept of the "anonymous Christian": Karl Rahner, Christiantity and the Non-Religions, in: Theological Investigations, vol. 5, London 1966, 115-134. 
support a position of epistemic inclusivism? I would like to defend the following position: The inclusivist position opens up the only conceptual possibility for a believer upholding the exclusivity of her own truth claims (against pluralism), without declaring the divergent belief, or the central truth claims of that belief, to be false (against exclusivism). Inclusivism and exclusivism share the view that the doctrines of the home religion are true and the truth claims of other religions incompatible with them are false. But inclusivism differs from (at least a traditional and more restrictive) exclusivism on the question, "whether it is possible for an alien religion to include any true claim among its doctrines and teachings." ${ }^{15}$ According to inclusivism, the exclusivity of a truth claim of the home religion excludes incompatible alien truth claims, though not a possible inclusion of the truth of the home religion in the alien belief system. The inclusivist can accept the fact of religious diversity and manage that fact conceptually without having to deny the superiority of her own standpoint. This kind of inclusivism should not be understood, as David Basinger claims ${ }^{16}$ as a derivative "soft exclusivism", but as a model in its own right that remains distinct from exclusivism and pluralism. Correct terminology is important here. Any position that acknowledges, theologically, the salvific force, or, philosophically, the inclusivity of at least one of its own basic truth claims within the tenets of a different religion, should be considered as an inclusivism and not as an inclusive or "soft exclusivism".

Yet how can one think that the other religious belief is possibly only partially true? Is such a view, and therefore the inclusivist position as a whole, at all tenable, bearing in mind the principle of bivalence contained in classical logic - according to which any proposition is either true or false, but not true and false at the same time, and therefore not 'partially' true? The inclusivist standpoint maintained by the Catholic Church for instance is based firstly on Biblical witness, and then on theological reflection concerning the radius and centre of the divine salvific will. Regarding the truth claims of other religions, the Second Vatican Council states with regard to other religions:

${ }^{15}$ Paul J. Griffiths, Problems of Religious Diversity, Oxford 2001, 57.

${ }^{16}$ David Basinger, Religious Diversity: A Philosophical Assessment, 5. 
The Catholic Church rejects nothing that is true and holy in these religions. She regards with sincere reverence those ways of conduct and of life, those precepts and teachings which, though differing in many aspects from the ones she holds and sets forth, nonetheless often reflect a ray of that Truth which enlightens all men. Indeed, she proclaims, and ever must proclaim Christ 'the way, the truth, and the life' (John 14:6), in whom men may find the fullness of religious life, in whom God has reconciled all things to Himself. ${ }^{17}$

This notion revolves primarily around St. Justin's Christian interpretation of the Stoic idea of the logos spermatikos. ${ }^{18}$ Theologically, this idea states that there are or may be 'grains' of truth in other religions; a "ray of that Truth" (radius illius veritatis) that Christians recognise in Christ shines through them. ${ }^{19}$ This passage implies a distinction between alethic inclusivism and relativistic inclusivism. Both versions hold that (a) there exists an absolute truth or set of true assertions about God. Only the latter holds that (b) no religion is able to ascertain fully the absolute truth or the complete set of true assertions about God and (c) every religion can at best ascertain partially the absolute truth or the true assertions about God. 'Inclusivism' in the Catholic sense refers to an alethic, that is truth-inductive inclusivism, which defends the position that one particular religion is able to ascertain, as the passage says, "the fullness" of God's truth in Jesus Christ.

But this might turn out to be more complicated than it seems at first glance; in light of the fact that within the Catholic tradition the concept of truth - without relativising the truth claim of the Church's own teach-

17 "Ecclesia catholica nihil eorum, quae in his religionibus vera et sancta sunt, reicit. Sincera cum observantia considerat illos modos agendi et vivendi, illa praecepta et doctrinas, quae, quamvis ab iis quae ipsa tenet et proponit in multis discrepent, haud raro referunt tamen radium illius Veritatis, quae illuminat omnes homines. Annuntiat vero et annuntiare tenetur indesinenter Christum, qui est 'via et veritas et vita' (Io 14,6), in quo homines plenitudinem vitae religiosae inveniunt, in quo Deus omnia Sibi reconciliavit" (emphasis added), in: Declaration on the Relation of the Church to Non-Christian Religions Nostra Aetate, no. 2. See also the Decree on the Mission Activity of the Church Ad gentes, no. 11 .

${ }^{18}$ Concerning this model from a theology of religious pluralism perspective, see: Jacques Dupuis, Toward a Christian Theology of Religious Pluralism, New York 1997, 53-60.

${ }^{19}$ Cf. Nostra Aetate, no. 2. 
ing - is construed historically, insofar as "every truth attained is but a step towards that fullness of truth which will appear with the final Revelation of God." ${ }^{20}$ This distinction between a 'truth attained' (veritas capta) and the 'fullness' of truth (veritas ultima) would entail, unintentionally, not alethic but a version of relativistic inclusivism. This distinction can be expressed within the metaphor found in Nostra Aetate, the document of the Second Vatican Council cited above. So, read in light of this distinction, we see that Christians, too, do not yet see all the rays of the Truth that is the event of Christ, but, in contrast to non-Christians, they do now see at least those rays that reveal it to be the event of Christ. This metaphorical view might explain why the Catholic tradition adheres to an alethic inclusivism. However, in the sentence of the Encyclical Letter Fides et Ratio about the distinction between the veritas capta and the veritas ultima it remains problematic, how under these conditions key tenets of Christian faith can be conceived of as being fundamentally final and irrevocable. This problem indicates that the talk of the logos spermatikos remains more of a metaphor, which does not take us very far in analyzing the basic problem of an inclusivist position.

The first question to be addressed is the meaning of inclusivity or inclusion in the term 'inclusivism. Based on the passage quoted from Nostra Aetate, inclusivity denotes the notion that a particular set of truth claims or at least one truth claim of a religion $P$ (here Christianity in the Catholic tradition) is contained, or included, in a different religion $S$. 'Inclusion' is tantamount to 'containment'. So literally, 'inclusion' means that a truth claim or a set of truth claims of $P$ is contained in $S$. The relation of inclusion is stated by a particular religion that assesses the occurrence of its own truth claims within the set of truth claims of different religions. It requires an outright interreligious commitment on the part of the inclusivist to analyse carefully the truth claims of different religions before stating any form of inclusivity.

How can the notion of inclusion be stated more precisely? Since set theory construes 'inclusion' as a particular relationship of containment between two sets of elements, it might be helpful to clarify the idea of

20 “... conscia sit omnem veritatem captam unam dumtaxat stationem esse plenam ad illam veritatem quae ultima in Dei revelatione ostendetur", in: John Paul II., Encyclical Letter Fides et Ratio, nos. 2-3. 
inclusivism in light of this insight from set theory. A set $A$ includes a set $B(A \supseteq B)$, if $B$ is a subset of $A$ and is contained in $A$. If there exists at least one element of $A$ which is not contained in $B$, then $A$ is also a proper superset of $B$, or, equivalently, $B$ is a proper subset of $A$. This relation is antisymmetric, because if $A \supseteq B$ with $A \neq B$, then $B \supseteq A$ is false. Assume, as an example, a relationship of inclusion between a religion $S$ with its truth claims $S_{1}, S_{2}, S_{3} \ldots S_{n}$ and a religion $P$ with its truth claims $P_{1}, P_{2}, P_{3}$ $\ldots P_{n}$. If $P$ is a proper subset of $S$, all the truth claims of $P$ must be contained in $S$ (so that $S_{1}=P_{1}, S_{2}=P_{2}$, and so forth) and there exists in $S$ at least one truth claim $S_{n+1}$, which is not contained in $P$.

However, it is clear that the model of inclusion of set theory thus articulated is not applicable to the issue of religious inclusivism. Even if the latter entails an antisymmetric relation between two religions (with a set of truth claims or only one truth claim of $P$ as a subset of the truth claims of $S$ ), $P$ could not be considered as a proper subset of $S$ insofar as not all truth claims of $P$ are contained in $S$. In this regard, the idea of inclusivism refers more to the intersection of two different sets, which contains all elements - i.e. truth claims - of $P$ that also belong to $S$. But on the other hand, the concept of intersection does not express an antisymmetric relation as it is implied in the notion of inclusivism.

Consider an example. Religion $P$ entails the three central and basic propositions $\{a, b, c\}$. Religion $S$ entails $\{b, c, d\}$, religion $T\{c, d, e\}$ and religion $U\{d, e, f\}$. Here, $P$ 's truth claims $b$ and $c$ are included in $S$, and its claim $c$ in $T$. No truth claim of $P$ is included in $U-$ but it would be possible for an adherent of $P$ to suppose that, for the time being, no truth claim of $P$ has yet been identified as contained in $U$. Even with this simple example, we can draw three conclusions for the position of inclusivism: there might be (1) one religion all of whose (or whose core) truth claims are true, (2) different degrees of inclusivity with regard to the number of truth claims of $P$ that are contained within different religions, (3) a hierarchy of religions from the perspective of $P$ according to the number of the truth claims of $P$ that they contain. It should be mentioned that this interpretation is simplified in that it focuses solely on the number of occurring truth claims. It is also possible - though I am not going to do so - to emphasise the meaning of truth claims within different religions and infer from that particular hierarchies. 
My explication of the core ideas of epistemic inclusivism shows us that there are epistemic advantages of inclusivism in comparison to exclusivism and pluralism. ${ }^{21}$ With regard to exclusivism, the position of inclusivism is better differentiated in terms of the relation between one's own religion and other religions. The traditional exclusivist analyses solely, under the principle of self-contradiction, the compatibility of the central truth claims of a different religion with his own core truth claims. In the case of incompatibility between these two sets of claims, the exclusivist tends to deny the truth and salvific force of the whole other religion - otherwise he would hold a form of inclusivism (as I have defined it). Inclusivism allows one to assert the absolute truth of one's own religion while affirming that salvation is also possible for non-Christians. With regard to pluralism, the idea of inclusivity sketched allows a religious person first to refer to her self-understanding and maintain the (nonmythological) truth of her single religion, and second to define a hierarchy of religions different from her true religion that are not completely false, but, on a sliding scale, partially true.

\section{AN EPISTEMIC FRAMEWORK FOR INCLUSIVISM}

Despite these advantages, this model of inclusivism still needs a more solid philosophical underpinning. How is it possible for the inclusivist to hold, on the one side, the exclusivity of truth claims of her own religion which excludes incompatible alien religious claims, and, on the other side, an inclusion of a truth claim or a set of truth claims of her religion in the alien belief? As was shown, the inclusivist maintains that only her religion $R$ is true and that there is a hierarchy of religions which are, on a sliding scale, either partially true (depending on the number and the meaning of contained true claims of $R$ ) or even false (because no truth claims of $R$ are contained). I would like to delineate only two aspects as an epistemic framework for the model of inclusivism:

${ }^{21}$ Recall that I am referring to a traditional and more restrictive form of exclusivism. A 'traditional exclusivist' holds that only her own religion is true if there are no core claims of an alien religion which are compatible with the core claims of Christianity (for example, the claim that salvation is only available through faith in Christ). 
(1) It is possible that different religions refer to the same God in different ways. This can be illustrated with a simple example: At $t_{1}$ observer $A$ sees from a distance that a tower looks round, whereas to observer $B$, who is even further away, the tower appears rectangular. ${ }^{22}$ At $t_{2}$, the persons get closer and both see that the tower is, in fact, round. Hence, at $t_{1}$ two contrary beliefs are held, but - as is revealed at $t_{2}$ - the two observers have been successfully referring to the same object. This clearly emerges as we consider the conditions of perception of the truth claim. At $t_{1}$ observer $B$ was able to give sound reasons for his belief, while from $A$ 's perspective it is clear that $B$ is not mistaken in referring to the same object, but is mistaken in his description thereof. From his perspective, $A$ has sound reasons to assume both that he is correct at $t_{1}$ and that $B$ is referring to the same object (for instance because $B$ is pointing at it). At this point it is helpful to distinguish three types of reference based on John Searle's theory of reference in Speech Acts:

(a) fully consummated reference, which identifies the object unequivocally,

(b) successful reference, which though not complete is successful,

(c) unconsummated and failed reference, which fails to lead to an identification of the object. ${ }^{23}$

Compared to both Quine's general skepticism with regard to the success of the act of reference (even within the system of one's own language), and the causal theories of reference developed by Kripke and the early Putnam, Searle's descriptive theory of reference has the advantage of conceptualizing the identification of the object of reference as a performative act, which with the aid of descriptors or markers can lead to unequivocal identification. Thus, according to Searle, successful reference is potentially fully consummated reference. ${ }^{24}$

It is precisely this transition that is at the stake in the example given above. The situation at $t_{1}$ is a case of successful reference: The tower is

${ }^{22}$ The example originates from Sextus Empiricus, Outlines of Pyrrhonism, chap. XIII, Cambridge (Mass.) ${ }^{2} 2000,69$ (I am grateful to Erik Baldwin for this hint).

${ }^{23}$ John Searle, Speech Acts, 82; Searle does not explicate separately the third form of reference.

${ }^{24}$ Ibid., 82. 
successfully identified as the object of reference by both $A$ and $B$, though only $B$ refers to it in an incomplete mode. Epistemic inclusivism might rephrase the performative act of reference as follows: From the internal perspective of a religion $E$, reference to God within the religion $F$ can be conceived of as a case of successful, though not complete, reference. ${ }^{25}$ It points in the right direction, allowing identification and thus distinction between God and idol, yet, from the internal perspective of $E$, still remains provisional compared to $E$ s own more precise reference. ${ }^{26}$ Consider, as an example in the field of religion, the following belief:

(B) The one God is not triune.

Both the Christian inclusivist and exclusivist share the view that (B) is incompatible with the Christian doctrine of the Trinity and, thus, agree that it is false. But, in contrast to the exclusivist, the inclusivist still can acknowledge that there is an 'element' of the Christian faith included in (B). Obviously, (B) contains the monotheistic belief that there is one God. So, in terms of reference, the inclusivist may argue that (B) is a case of a successful reference to the object of the Christian belief, in which case (B) is able to identify the Christian God but remains incomplete given that (B) does not acknowledge God's triune existence. The exclusivist cannot grant there is an element of truth in (B). See, for instance, the following definition:

Exclusivism maintains that the central claims of Christianity are true, and that where the claims of Christianity conflict with those of other religions the latter are to be rejected as false. Christian exclusivists also characteristically hold that God has revealed himself definitively in the Bible and that Jesus Christ is the unique incarnation of God, the only Lord and Savior.

${ }^{25}$ Of course this is not to say, as John Hick's pluralist theology of religions might, that all religions refer successfully, though necessarily imperfectly, to a transcendent reality.

${ }^{26}$ Can religion $E$ still revise its strong and central beliefs? From $E$ 's internal perspective, its own truth claim is, at root, the certainty that no such revision will take place, either at $t_{3}$ or at $t_{\mathrm{n}}$. However, the foundational certainty that this involves relates only to the successful identification of the object of reference 'God', not to the scope of the set of propositions that can be predicated by it. This becomes clearer when we consider aspect (b). 
Salvation is not to be found in the structures of other religious traditions. ${ }^{27}$ Exclusivists and inclusivists share the view that claims which are incompatible with their own religious claims are false. But the inclusivist is not therefore automatically forced to reject the other religion. With regard to the incompatible claim of the other religion the inclusivist is able to examine carefully whether it is based on an unconsummated and failed reference (and is therefore false) or on a successful though incomplete reference (and is therefore at least partially true). Thus, accepting incomplete reference to the same object permits the inclusivist to accept that 'false statements' about that object may be partially true. This view is available only to the inclusivist but not to the exclusivist - otherwise the latter would hold some sort of 'covert inclusivism'. This idea of an incomplete though successful reference does not only apply to particular truth claims but also to religions as theories.

(2) Understood as theories, religions are under-determined and, with respect to the scope of the set of propositions that they uphold, not necessarily complete. For instance, if we understand the belief system of a religion as theory $T_{1}$ with the truth claims $S_{1}, S_{2}, S_{3} \ldots S_{n}$, then from an internal perspective it is not ruled out that $T_{1}$ might, in light of 'progress towards the fullness of truth' develop into $T_{2}$ with the truth claims $S_{1}, S_{2}$, $S_{3} \ldots S_{n}, S_{n+1}$ (broadening of the set of propositions) or $S_{1^{*}} S_{2^{*}}, S_{3^{*}} \ldots S_{n^{*}}$ (unfolding or revision of certain propositions or attitudes). Within the Catholic Church, numerous examples of this can be found in the history of dogma. Examples of broadening include for instance the Mariological dogmas of the $19^{\text {th }}$ and $20^{\text {th }}$ centuries. Examples of revision include attitudes towards the freedom of religion. And examples of unfolding include the understanding of revelation. This insight entails recognition of a certain form of doctrinal contingency: From the internal perspective of a given religious community, its own teaching is true at $t_{1}$, while it is not excluded that this truth may be capable of being expressed more comprehensively and precisely at $t_{2}$. If a religious tradition disputes such

${ }^{27}$ Harold A. Netland, Dissonant Voices: Religious Pluralism and the Question of Truth, Vancouver 1997, 9. See also ibid., 112: "Christian exclusivism . . . contends that where the central claims of Christian faith are incompatible with those of other religious traditions the latter are to be rejected as false. Thus, for example, it has traditionally been said that the Muslim and the orthodox Christian cannot both be correct in their respective beliefs about the identity of Jesus of Nazareth." 
underdeterminedness and thus the possibility of extending or deepening of its core beliefs, then it can only be described as radically exclusivist.

With regard to the notion of inclusivity, the two aspects allow for the possibility that a particular religious truth claim as well as a religious belief can be considered as being "approximately true". ${ }^{28}$ On the basis of this interpretation, it is possible to reconstruct an inclusivist position philosophically, while still upholding the ultimate truth of a certain veritas capta, yet without excluding the possibility that the veritas ultima might be more comprehensive and profound.

\section{CONCLUSION}

Inclusivism is not, as John Hick claims, a "somewhat astonishing doctrine". Against Hick's pluralism, the inclusivist holds that religions are referring successfully to God. Hick maintains that substantial properties (such as 'omnipotence' or 'being a person') cannot be ascribed to the divine reality ${ }^{29}$ and that religious truth claims are, at best, mythologically but not literally true. ${ }^{30}$ We now see how it is that, for Hick's pluralism, religions are unable to refer successfully to the divine reality. Because of the transcategoriality of the divine reality, reference to what religions call 'God' or 'Allah' or whatever is unable, according to Hick's theory, to identify the divine reality in itself. So when Hick, for example, points out unequivocally that "the ultimate reality, the Real, cannot be described as a personal God", it follows that within Hick's pluralism the Christian attempt to refer to God as a person remains unsuccessful as it fails to identify God as he is in himself. ${ }^{31}$

${ }^{28}$ Cf. Laurence BonJour, Reply to Solomon, in: Philosophy and Phenomenological Research 50 (1990), 779-782, 779f. See also: Lorenz B. Puntel, The Rationality of Theistic Belief and the Concept of Truth, in: Godehard Brüntrup/Ronald K. Tacelli (eds.), The Rationality of Theism, Dordrecht 1999, 39-59, here 53, who speaks of a relative "truth status": "Only at the end of the day, that is, when all factors (data, aspects, alternatives, and the like) have been taken into account and examined, will it be possible to establish 'the truth', that is, the fully determinate status of the sentences stated and the propositions articulated."

${ }^{29}$ See John Hick, An Interpretation of Religion: Human Responses to the Transcendent, New Haven/London 2004, 239.

${ }^{30}$ Ibid., xix-xxii, 348.

${ }^{31}$ For an attempt to clarify Hick's theory with regard to reference see Peter Byrne, 
Against exclusivism, and without relinquishing the exclusivity that is logically inherent in her truth claims, the inclusivist can (i) accept a plurality of heterogeneous attitudes and thus co-exist at least with a minimal pluralism, (ii) on the basis of her own doctrinal contingency even learn from this other position and supplement or deepen her own teaching, and (iii) when faced with another religious belief or conviction, ascribe to that other position an inclusivity of truth claims of the home religion. That is, she can consistently concede that members of other religions make successful although incomplete references to God. Thus, a form of moderate exclusivism should not be called 'inclusivism' if it identifies the inclusivity of, at least, one of its own truth claims within the tenets of a different religion.

As we know, divergent truth claims of religions harbor a particular potential for both ethical and political conflict. They do so on the one hand when combined with a radically exclusivist attitude, and when they involve both strong and exemplary beliefs, thus creating a clash of world views upon which identities are constructed. They do so, on the other hand, when the members of the religious communities concerned lack sufficient intellectual and social competence to manage these conflicts both cognitively and politically, and to call into question an unjustified coherence of strong religious and political beliefs. The inclusivist model is empirically and epistemically the most viable position to adopt in response to the challenge of the plurality of religious truth claims. In my opinion, the challenge of the plurality of religious views consists first and foremost in the problem of whether the members of a religious community are willing to acknowledge their particularity de facto, without therefore having to relinquish the truth claim of their own religion. In this respect the concept of epistemic inclusivism offers major advantages. ${ }^{32}$

\footnotetext{
Prolegomena to Religious Pluralism: Reference and Realism in Religion, London 1995, 31-55, 191-203.

${ }^{32}$ I am grateful to Jeremy Neill and especially to Erik Baldwin for their comments on an earlier draft of this paper.
} 